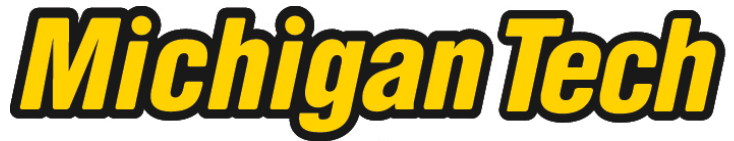 \\ Michigan Technological University Create the Future Digital Commons @ Michigan Tech
}

\section{MIGRATION PATTERNS AMONG YOUNG ADULTS IN THE UNITED STATES: ENVIRONMENTAL, SOCIAL, AND ECONOMIC EXPLANATIONS}

Fangming Liu

Michigan Technological University

Follow this and additional works at: https://digitalcommons.mtu.edu/etds

Part of the Environmental Sciences Commons, and the Sociology Commons Copyright 2013 Fangming Liu

Recommended Citation

Liu, Fangming, "MIGRATION PATTERNS AMONG YOUNG ADULTS IN THE UNITED STATES:

ENVIRONMENTAL, SOCIAL, AND ECONOMIC EXPLANATIONS", Master's Thesis, Michigan Technological University, 2013.

https://doi.org/10.37099/mtu.dc.etds/675

Follow this and additional works at: https://digitalcommons.mtu.edu/etds

Part of the Environmental Sciences Commons, and the Sociology Commons 
MIGRATION PATTERNS AMONG YOUNG ADULTS IN THE UNITED STATES: ENVIRONMENTAL, SOCIAL, AND ECONOMIC EXPLANATIONS

By

Fangming Liu

\begin{abstract}
A THESIS
Submitted in partial fulfillment of the requirements for the degree of MASTER OF SCIENCE

In Environmental and Energy Policy
\end{abstract}

MICHIGAN TECHNOLOGICAL UNIVERSITY

2013

(C) 2013 Fangming Liu 
This thesis has been approved in partial fulfillment of the requirements for the Degree of MASTER OF SCIENCE in Environmental and Energy Policy.

Department of Social Sciences

Thesis Advisor: $\quad$ Richelle L. Winkler

Committee Member: Bradley H. Baltensperger

Committee Member: Mark D. Rouleau

Department Chair: $\quad$ Patrick E. Martin 


\section{Tables of Contents}

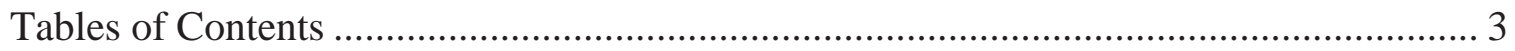

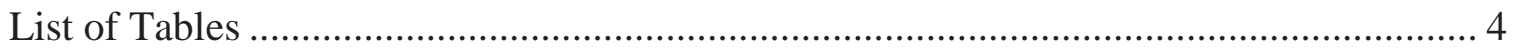

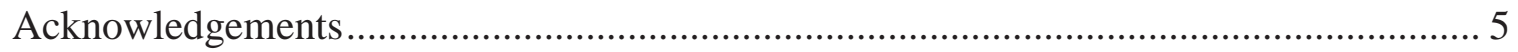

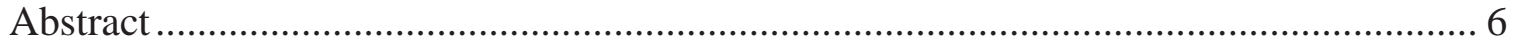

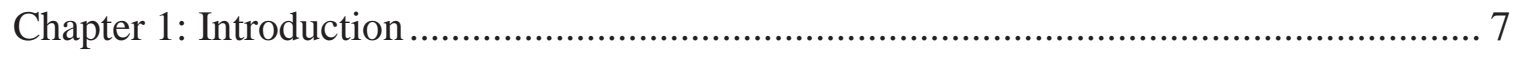

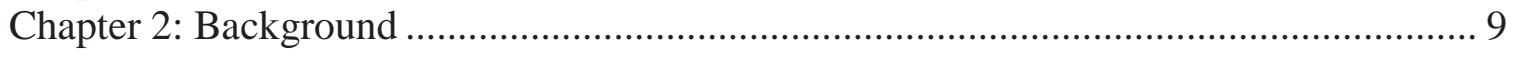

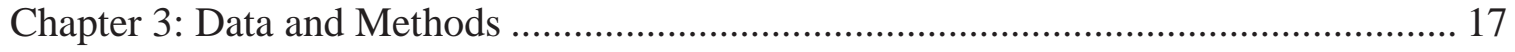

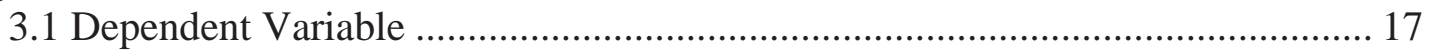

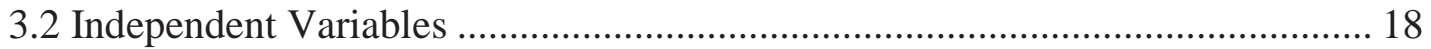

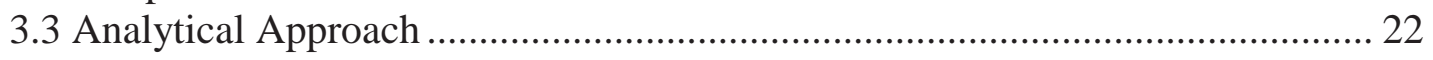

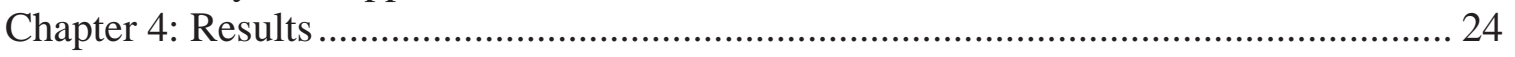

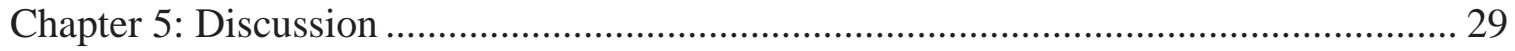

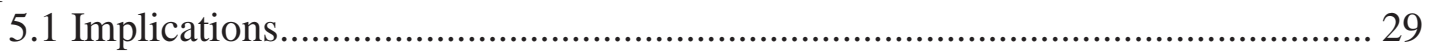

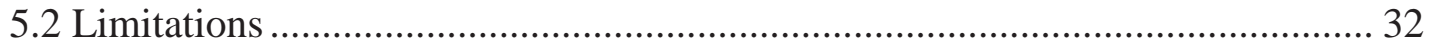

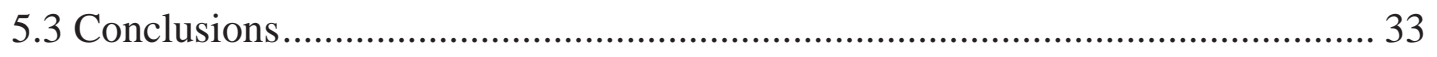

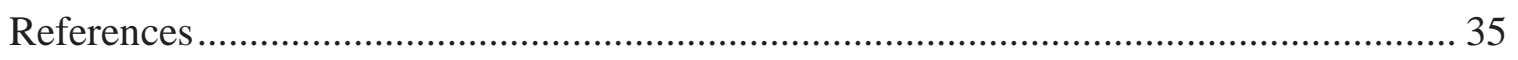

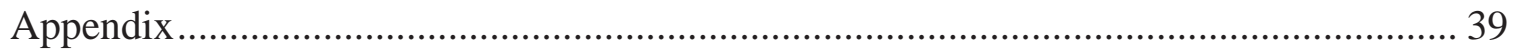




\section{List of Tables}

Table 1: Linear Regression Results for Economic, Social, Environmental, and Full Models 25

Table 2: Summary Statistics of Net Migration Rate for Each County Type .................... 27

Table 3: Linear Regression Results for Full Models of Central City Counties, Rural Counties, and Small City Counties Respectively 28

Table A: Description of all the independent variables that have been tried ..................... 39

Table B: Results of variance inflation factor of each independent variable in the Table 1 


\section{Acknowledgements}

Foremost, I would like to express my sincere gratitude to my advisor Dr. Richelle Winkler for her continuous support of my master study and research, and for her patience, motivation, enthusiasm, and immense knowledge. Her guidance helped me in all the time of research and writing of this thesis.

Besides my advisor, I would like to thank the rest of my thesis committee: Dr. Bradley Baltensperger and Dr. Mark Rouleau, for their encouragement, insightful comments, and kindness.

My sincere thanks also go to Dr. Barry Solomon, for accepting me in this program and Dr. William Breffle, for encouraging me to apply for this program.

I highly appreciate Rhianna Williams' help for data collection, and for her great patience and support.

I thank my friends in the United States: Siranee Nuchitprasitchai, Diana Liu, and Fei Li for their tolerance, support, help, and all the fun we have had in the past two years. I also give thanks to my friends in China: Hongya Si, Hailing Zhang, Nana Li, and Shanshan Tian for their constant care and support. In particular, I am grateful to Dr. Xiaoran Wang for all his encouragement.

Last but not least, I would like to thank my family: my parents Yan'gang Liu and Qi Wang, for supporting me physically and spiritually throughout my life. 


\begin{abstract}
Young adult migration is a key factor in community development. The goal of this paper is to study what kinds of places attract young adults and what kinds are losing them. Linear regression is conducted to analyze what place-specific factors explain migration patterns among young adults. These factors include economic, social, and environmental variables. This study finds that social and environmental factors are just as important as economic ones. Specifically, employment in the arts increases young adult net migration. Environmental variables, for example, natural amenities and protected federal lands are particularly important in rural settings in attracting young adults. These findings suggest that policy makers interested in attracting and retaining young adults should pay closer attention to social and environmental factors and consider creating more opportunities for arts employment in general. For rural areas, improving the attractiveness of natural amenities and better protection of federal lands is also recommended.
\end{abstract}

Keywords: young adult migration, community development, environmental policy, arts, natural amenities 


\section{Chapter 1: Introduction}

Migration has dramatic impacts on population change, especially at more local levels, which influences community vitality not only by changing the size of the population, but also by changing the age structure, educational attainment, income, and labor force status of the population (Winkler et al. 2012). Well-educated young adults increase local human capital, which is the foundation of labor force and community development (Winkler et al. 2012). Loss of such human capital in a community results in decreased productivity and local economic growth (De Jong and Legazpi 1994), which makes it difficult for long-run community development. This paper analyzes migration patterns of U.S. young adults, ages 25 to 29 years in 2010. All the counties in the contiguous U.S. are examined to understand what characteristics of places attract or repel young adults. More specifically, this study examines the extent to which environmental, as well as social and economic, factors affected young adult net migration between 2000 and 2010.

Nonmetropolitan counties within the United States are particularly interesting and important in this study. Nonmetropolitan America is generally experiencing an aging trend partly due to the outmigration of young adults with negative economic development consequences (Glasgow 2000; Johnson \& Beale 2003; Whitener \& Parker 2007). In this context, young adult outmigration is an important economic and community development concern (Mills and Hazarika 2001). 
Moreover, nonmetropolitan areas of United States (and world) are usually rich in natural resources. Many rural areas serve as stewards of natural resources and are important for delivering ecosystem services. For example, we depend on ecosystem services to produce our food, regulate our water supplies, and protect us from extreme weather. We also benefit from recreational enjoyment that nature provides us. Therefore, ecosystem and its services are critical for developing long-term sustainable communities. Given this importance, rural areas are important places for environmental policies to protect. Understanding how environmental, social, and economic factors affect young adult migration has implications for environmental policies in explaining resource related questions and policies aimed at promoting rural sustainable community development. For example, policies aimed at protecting lands in rural places are controversial, because some people think such policies restrict population and economic growth while other people believe that such policies can help conserve natural resources and attract more people. This study will find out whether we should preserve lands for environmental protection or develop lands for economic benefits. In a word, this research can inform planners and community developers of means through which they may be able to reshape local communities to slow down the outmigration of young adults and attract incoming young adults. 


\section{Chapter 2: Background}

Migration is highly selective by age (Winkler et al. 2012; Plane et al 2005).

Johnson et al. (2013) demonstrate that certain age groups migrate in similar ways. For instance, migration patterns of those who are at or near retirement age are more sensitive to amenities and family considerations, while people at college age move to places with more opportunities for education (Johnson et al. 2013). In addition, Greenwood (1988) found that young adults are a highly mobile population and are more likely to migrate than other age groups. Therefore, we should pay more attention to young adult migration due to its great influence on community development (Greenwood 1988).

While people have studied age-specific migration patterns for decades, the characteristics of places that influence these patterns are not well understood. Prevailing wisdom has been focused on economic reasons. People follow jobs, but jobs can also follow people. Researchers found that lack of job opportunity is one of the main reasons to explain migration (Artz 2003; Greenwood 1975; McGranahan et al. 2010). Mill and Hazarika (2001) explain more specifically that employment opportunities for highly educated young adults are relatively skill-specific and rural areas usually lack such job opportunities, which drive those young adults away from rural areas. Whitener and Parker (2007) support Mill and Hazarika's explanation that the few local employment opportunities for highly educated young adults push those who prefer to stay in their counties of origin to take jobs that poorly match their specific skills with lower pay, and this unmatched situation is likely to push those young adults away from their homes. 
Moreover, research on economic explanations of young adult migration patterns suggests that not only is job availability a factor, but low potential wages also push young adults out of more rural areas (Albrecht 2012; Corbett 2007; De Jong and Legazpi Blair 1994; Domina 2006; Grau and Aide 2007). They agree that people usually migrate to seek better jobs with higher income. The expected returns to specific skills and education are higher in urban areas, which give cities an advantage in attracting college-educated young adults. This also answers the question why young adults migrate from rural areas to urban cores. It is better for young adults with a higher degree of education and specific skills to find higher paid and skill-specific jobs in metropolitan areas than rural areas. Greenwood and Hunt (1989) specifically examine the effects of wages on the inmigration to metropolitan areas and show that nothing is more powerful than real wages to influence such migration.

Net migration is also associated with employment growth, which reflects the generation of new job opportunities and productivity growth conditions (Cebula and Alexander 2006; Greenwood 1989). Wojan et al. (2007b) agree that net employment growth is another potential economic driver for young adult net migration, which is very commonly used as an indicator of economic dynamism. In addition, Davis and Weber (2002) demonstrate that the effect of local job growth on influencing young adult migration may be weaker in rural areas than in urban ones.

However, some counties with lower unemployment rates and a higher average household income, which can be called prosperous counties, are still experiencing high net outmigration (McGranahan et al. 2010). This indicates that economic factors are not the only reason why some counties are losing young adults. There must be some other 
factors that can explain young adult outmigration. Social factors, including access to public services, like schools, doctors, food stores, and restaurants, are also important factors (Malecki 2003; McGranahan and Beale 2003). Whitener and Parker (2007) agree that the access to telecommunication, water, waste disposal systems, and transportation infrastructure (such as highways and airports) is important for people when considering their migration destinations. For example, places without a commercial airport may be less attractive for young adults due to its inconvenience for them to travel to other places. Remote rural areas usually lack access to public transport to other places, which make it a disadvantage to attract and retain young adults.

Florida (2002) found that creative people and economies and the types of places that foster creative atmospheres are key driving forces for economic development of postindustrial cities in the United States. He argues that cities with a larger population of the creative class are more prosperous, because the creative people are usually the main force of industries and the in-migration of creative people have generated more local jobs and boosted local economy. Therefore, Florida (2002) encourages regional developers to create an environment that attracts and retains creative workers. Based on Florida's creative theory, those places with a higher share of creative class suggest better local economic conditions, which may attract young adults.

However, critiques arise that the creative class does not have a real causal relationship with economic growth in metropolitan cities and suffers circular logic (Peck 2005). McGranahan and Wojan (2007) state that the positions included in the creative class should be narrowed down to be specifically linked to high paying jobs. Möller and Tubadji (2008) supplement that the artists should be separated from Florida's definition 
of creative class due to the substantive difference between the artists and other positions included in the creative class, like CEOs and engineers. However, art employment is also associated with community development, which may influence young adult net migration. Lowe (2000) found that arts serves as catalyst for developing community, because it connects local people by generating social bonds of solidarity and setting up community identity, which is very important for developing sustainable community. Taking the above into consideration, Wojan et al. (2007b) state that the higher share of visual, applied, and performing artists and authors (Bohemian share) in a community suggests a stronger support for social and cultural interactions which are associated with population growth. They find that places with more artists usually have more art museums, art schools and historic sites, which implies that people living in those communities value their community history and heritage and would like to make good use of them to set up their cultural identity. Besides, Wojan et al. (2007b) show that the Bohemian share and other factors, such as natural amenities, outdoor recreations, and the number of colleges in a place, are positively related to one another.

Researchers take racial and ethnic diversity as another important social factor that can explain migration patterns. There are two competing perspectives towards the impacts of race and ethnicity on young adult net migration. Frey (1980) stated that whites are moving away from those places, which have larger minority population. McGranahan et al. (2011) agree that minority populations remain at a disadvantage from an economic aspect, so that it may have an adverse impact on the overall local economic growth, which may push young adults away. On the other hand, Becker (1998) argues that racial inclusion is vital for community development. She stresses the importance of racial 
congregation and proposes relative strategies to get more minorities involved, indicating that a community with a higher percentage of nonwhites is more inclusive and tolerant for racial identity, which may be preferable for young adults. Besides, Florida (2002) found that racial and ethnic diversity attracts creative young people.

Beyond economic and social factors, environmental factors might play a critical role in predicting young adult migration patterns, but to date, this relationship remains underexplored. This is particularly true in the most recent decade with gradually rising environmental concern, especially for those young adults who are known to have great environmental awareness (Jones and Dunlap 1992). Therefore, negative environmental factors, like environmental hazards, which threaten human health, might drive young adults away. Meanwhile, positive environmental amenities, such as national parks, which provide beautiful scenery for visitors, might attract migrants. Much has been written about environmental amenities attracting retirees to places rich in natural resources (Lorah and Southwick 2003; McGranahan 1999), but little research investigates the extent to which environmental factors drive young adult migration.

Environmental hazards and degraded ecosystems make places less attractive (Black et al. 2011). Hunter (2005), Rupasingha and Goetz (2004), and Daniels and Friedman (1999) discuss the negative environmental factors which make a place less attractive. Hunter (2005) points out that people, especially those who are risk-averse, are trying to move out of the places with high frequency of environmental hazards to their health, like volcano and tsunami threats. Cebula and Alexander (2006) and Rupasingha and Goetz (2004) find that the presence of a Superfund site in a place, or the higher a county is on the Environmental Protection Agency (EPA)'s hazards ranking system, the 
less attractive that place is. In addition, Daniels and Friedman (1999) demonstrate that air pollution from manufacturing is unevenly distributed across counties in the U.S, which may also influence the migration patterns among young adults.

While environmental hazards and other environmental-related risks may represent negative locational characteristics, positive environmental attributes increase attractiveness of destinations. McGranahan and Beale (2003) use a natural amenity scale to measure environmental attractiveness of a place to live, which consists of six items: average January temperature, days of sun in January, temperate summer, low July humidity, percent of county that is surface water, and topological variation. McGranahan (1999) concludes that counties scoring high on the natural amenity scale have had substantial population growth in the last 25 years. Glasgow (2000) supports the above conclusion that natural amenities are magnets for in-migration and tourism. Cebula and Alexander (2006) have specifically examined the relationship between warmer temperature and net migration and found it positive. In addition, Black et al. (2011) and McGranahan (1999) found that natural amenities are associated with employment conditions. For example, McGranahan (1999) shows that counties low on the natural amenity scale may have had relatively little employment growth in the late $20^{\text {th }}$ century, while the employment of counties scoring high grew three times as many new jobs in 1996 as in 1969.

Land also plays an important role in influencing young adult migration. McGranahan (2008) states that people have been most drawn to the areas with a mix of forest, open land, and water area, which have high topographical variations. For example, Johnson and Beale (2003) found that population gain usually happens in recreation 
counties which are mostly located in the Mountain West and Upper Great Lakes areas. These counties are either lake-orientated or have winter attractions, such as snowmobile trails and skiing. Those places have more federal land with more recreational opportunities, which may be attractive for young adults. Lorah and Southwick (2003) demonstrate that the presence of the protected federal lands encourages population growth by attracting tourists and new residents. They further find that environmental protection is correlated with relatively rapid population growth, high income, and employment growth.

Taken together, the above studies suggest that economic, social, and environmental factors may all play a role in explaining young adult migration. This paper makes four important contributions to the literature on young adult migration patterns. First, it investigates the relative importance of all three types of potential influential factors. Previous research finds economic factors are most important for young adult migration (Tichamyer and Duncan 1990; De Jong and Legazpi Blair 1994; Mill and Hazarika 2001; Domina 2006). However, times are changing, maybe now with the most recent data and the rise of public environmental concern, environmental variables have become critical in explaining young adult migration as well. The potential findings about the influence of environmental variables will help policy makers to design better environmental policies to develop communities sustainably.

Second, this study takes all the counties in the United States into consideration. It presents a broader integral view of young adult migration. Most other studies are case studies about the migration among some specific kinds of places, like rural to urban migration (Nor 1979; Driscoll et al. 2010; Grau and Aide 2007). 
Third, this study discusses the characteristics of places. I can learn migration patterns among young adults from a different perspective than an individual level, which previous wisdom mainly focuses on (Lee and Roseman 1999; LeSage and Ha 2012; Singh and Yadava 1981). In other words, most other studies pay close attention to the explanation of why people decide to move and what factors determine their choices of destination places. What they are missing is the study of places.

Finally, this study focuses on the migration of young adults, which is very important for community development, because young adults are the mainstay with most updated information and skills to boost local economy (Glasgow 2000). Prior research focuses mainly on the migration of retirees. They primarily study the in-migration of elderly people, which causes the aging problem. However, the out-migration of young adults is also a key driver of the aging problem of local community, so it is important to investigate. 


\section{Chapter 3: Data and Methods}

This study includes all of the counties within the contiguous United States $(\mathrm{N}=3108)^{1}$. Counties are the unit of analysis because they have historically stable boundaries and are a basic unit for reporting demographic, social, and economic data (Beale and Johnson 1998, Johnson et al. 2005). The target population is young adults, who were age 15 to 19 at Census 2000 and age 25 to 29 at Census 2010. By conducting a broad quantitative analysis, we can learn what kinds of places attract young adults in general. This provides us with a broader view of what characteristics of places are the most appealing to young adults, which case studies cannot do.

\subsection{Dependent Variable}

The dependent variable is the net migration rate of those young adults. Young adult net migration rate is a nationwide, county-level dataset developed by Winkler et al. (2013) using a residual method of calculating the net migration rate ${ }^{2}$ between 2000 and 2010 for U.S. counties by five-year age group. Young adults are highly mobile compared to other life stages. Most young adults in this age group have already finished their studies in college or high school and are looking for jobs. They are a key piece of the labor force and contribute to economic growth and community development. Therefore, the characteristics of their destinations are of interest. The goal is to find out what kinds

\footnotetext{
${ }^{1}$ Alaska, Hawaii, and Puerto Rico are excluded in this analysis.

${ }^{2}$ Net migration rate $=($ net migration/expected population in 2010$) * 100$. Net migration $=$ the actual population in 2010 - the expected population in 2010 . The expected population in $2010=$ the population from Census 2000 + the number of people born in 2000s - the number of people died in 2000s.
} 
of places are losing these young adults and what kinds of places are gaining, retaining, or losing fewer of them. In other words, this paper is trying to show what economic, social, and environmental characteristics of places explain young adult net migration.

\subsection{Independent Variables}

As discussed above, the literature suggests that income, unemployment rate, and job growth are important economic variables in explaining migration patterns among young adults. Furthermore, the literature implies that airport distance is an important social variable which represents the convenience for young adults to travel to other places. Bohemian share and percentage of whites are other two significant social variables to explain young adult net migration, which capture cultural diversity and racial diversity, respectively. Besides, natural amenities, percentage of protected federal lands, and the presence of a superfund site are significant environmental variables measuring either the attractiveness or the risk of a place to live.

The independent variables ${ }^{3}$ include economic, social and environmental variables. Most data are collected in 2000 because the year of 2000 is the starting point when young adults began their migration journey in this research ${ }^{4}$. The following is a list of independent variables with the hypotheses based on literature:

\section{Economic Variables}

\footnotetext{
${ }^{3}$ Summary statistics of all the independent variables is shown in Appendix I.

${ }^{4}$ Some of the data are not from the year of 2000, because some data are newly released for recent years and/or does not vary much through years. For instance, the distance from the county boundary to the nearest commercial airport does not change much through years.
} 
Median household income is measured as the median value of a household's income in 1999. It is hypothesized to increase young adult net migration. Data are available from U.S. Census 2000 Summary File 3 (SF3).

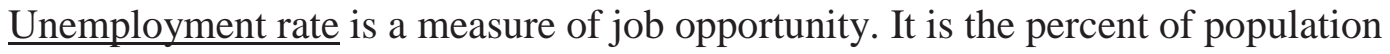
in the labor force that was unemployed in 1999. It is hypothesized to decrease young adult net migration. It is available from the U.S. Census 2000 Summary File 3 (SF3).

Job growth measures change in the number of jobs between 2000 and 2010 divided by the number of jobs in 2000. It represents the potential expansion of the job market. It is hypothesized to have a positive relationship with young adult net migration. Data of the number of jobs in 2000 and 2010 can be accessed at County Business Patterns (2010).

Social variables

Airport distance captures the availability of public transportation for young adults to travel to other places. It measures the distance in miles from the county boundary to the nearest commercial airport. If a county has a commercial airport in it, the miles equals zero. It is hypothesized to negatively affect young adult net migration, because the closer a county to an airport, the more convenient it is for young adults to travel to other places. Therefore, short distances may attract more young adults. Winkler (2010) calculated this variable using data from ESRI (2007) on location of commercial airports.

$\underline{B o h e m i a n}$ share refers to the share of employment in the arts, which includes visual, applied and performing artists and authors, in 2000. It captures the creativity, diversity, and the cultural opportunities in a community. It is hypothesized to increase 
young adult net migration. It can be accessed from Economic Research Service (ERS) of the U.S. Department of Agriculture (USDA) (2000).

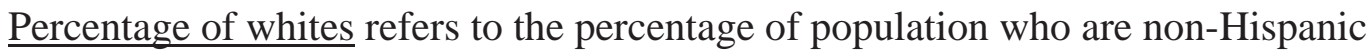
whites. It is also a social factor to represent racial and ethnic diversity of a community. Some people believe that higher percentage of whites will increase young adult net migration rate, because places with a larger population of whites usually have better economic condition, which attracts young adults (Frey 1980; McGranahan et al. 2011). While some other people believe that higher percentage of whites will decrease young adult net migration rate, because those places are not tolerant for racial identity, which young adults dislike (Becker 1998; Florida 2002). Data can be accessed from U.S. Census 2000 Summary File 1 (SF1).

Environmental variables

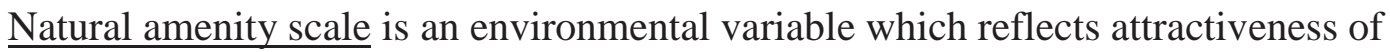
a place to live. The scale was constructed by combining six measures of climate, topography, and water area. These measures are warm winter, winter sun, temperate summer, low summer humidity, topographic variation, and water area. It is hypothesized to increase young adult net migration. It is accessible from Economic Research Service (ERS) of the United States Department of Agriculture (USDA) (1999).

Percentage of protected federal land measures the proportion of land area that is protected (not available for extractive resource development) federal land (owned by federal government) within a county. It is hypothesized to positively affect young adult net migration, because it may provide more outdoor recreational opportunities for young 
adults (Williams and Winkler 2013). Data are available from Williams and Winkler's work (2013).

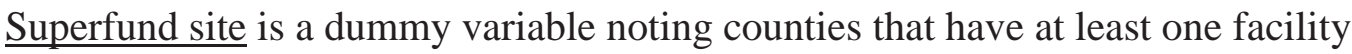
on the National Priorities List (Superfund). A Superfund site, which is an uncontrolled or an abandoned place where hazardous waste is located, is possible to have an adverse impact on local ecosystems and human health. Therefore, it is hypothesized to decrease young adult net migration. Data are derived in GIS from the EPA Shapefile, posted 8/12/2009.

\section{Control variables}

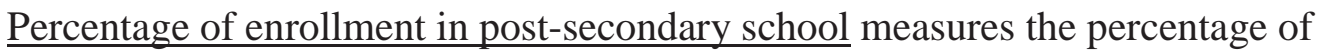
population enrolled in post-secondary school in 2010. Migration due to the enrollment of post-secondary school is involuntary migration for young adults. It does not reflect the young adults' preferences for their destinations. Therefore, this variable was controlled while analyzing the model. Data are available from American Community Survey 20062010.

The percentage of population in military is a measure of young adults who move for military purposes, which are included in the net migration data. It is another kind of involuntary migration, so it is controlled in the analysis. Data are accessible from American Community Survey 2006-2010. Data are measured in 2010, because 2010 is the ending point those young adults moved to such places.

The percentage of population in prisons measures the possibility that young adults, who are originally from big cities, are caught in prisons located in rural areas. This is also involuntary migration which is included in young adult net migration data, the percentage 
of population in prisons is controlled in the model. Data are available from U.S. Census 2010. Data are also measured in 2010 , because the year 2010 is the ending point for such migration.

Central city is a dummy variable noting counties that have at least one city of at least 200,000 people at Census 2010. It captures the urbanity of a county. Young adults are moving to central cities due to central cities' superiority in many aspects, not only better economic conditions. In general, central cities have more things to see and taste than rural areas. It can offer young adults a sense of adventure living in a central city. Therefore, it is necessary to control it to exclude such impacts of urbanity on young adult net migration.

$\underline{\text { Rurality }}$ is another dummy variable. Rural counties are those counties that have a total urban population less than 20,000 in 2013. Data stems from 2013 Rural-Urban Continuum Codes (2013 RUCC), which is available from Economic Research Services (ERS) of the United States Department of Agriculture (USDA) (2013).

\subsection{Analytical Approach}

This study employs linear regression models based on Ordinary Least Squares (OLS) methods to analyze the relative impacts of economic, social, and environmental variables on young adult net migration rate. The goal of the first group of regression models is to compare relationships between economic, social, and environmental factors and young adult net migration rate. The first set of regression models includes all the counties within contiguous United States. Economic, social, and environmental models

are conducted separately. Each regression model includes all control variables to exclude 
the impacts of institutions, urbanity, and rurality on young adult net migration rate. A full model, which includes all independent variables in one model, is conducted following these three separate models to examine which specific variable works better in the explanation of young adult net migration. By comparing the adjusted $\mathrm{R}^{2}$ and F-value of different models, we can evaluate which model explains young adult net migration better in general. We can also compare each variable's standardized coefficient and t value to examine each variable's relative influence on young adult net migration rate.

The second group of regression models investigates how relationships between dependent and independent variables vary across levels of urbanity. I do this by grouping all the counties within the contiguous United States into three categories. A county is categorized as a central city county if it has at least one city of at least 200,000 people at Census 2010. A county is classified as a rural county if it has a total urban population no more than 20,000 in 2013 . Other counties are categorized as small city counties. All the independent variables and control variables are included in each model to compare the impacts of different factors on young adult net migration among different levels of urbanity. We can see whether the relationship between the dependent variable and the independent variables varies among different levels of urbanity and rurality. This approach tests whether rural counties have the same drivers with urban counties in explaining young adult net migration. 


\section{Chapter 4: Results}

Model results indicate that social and environmental explanations for young adult net migration fit as well as economic explanations. The Bohemian share, which represents arts employment, is highly associated with increased young adult net migration. Environmental variables, specifically natural amenities and protected federal lands, are significantly important in influencing young adult net migration, especially in rural areas.

Table 1 shows results of economic, social, and environmental models and then results of the full model. In the economic model, only median household income is statistically significant. It has a positive coefficient as expected, which means places with higher median household income are associated with increased net migration of young adults. In the social model, all variables are statistically significant. Airport distance has a negative coefficient as hypothesized, which means the farther away the county boundary is from a commercial airport, the less attractive that county is for young adults. Bohemian share has a positive coefficient as expected. It means arts based employment is associated with increased net migration among young adults. Percentage of non-Hispanic whites has a negative coefficient sign, which means young adults prefer those places which are more diverse, inclusive and tolerant towards racial identity. It might also be capturing affordability. Places with larger minority populations are usually more affordable, which attracts young adults. In the environmental model, natural amenity scale has a significant positive relationship with net migration, which means those places which have a higher score on the natural amenity scale are associated with increased net migration among 
young adults. Percentage of protected federal land is also associated with an increase in net migration among young adults. The presence of a Superfund site is not statistically significant, indicating that the presence of superfund site does not play a significant role in explaining young adult migration.

Table 1: Linear Regression Results for Economic, Social, Environmental, and Full Models 5,6

\begin{tabular}{|c|c|c|c|c|c|c|c|c|}
\hline \multirow[b]{2}{*}{ Variables } & \multicolumn{2}{|c|}{ Economic } & \multicolumn{2}{|c|}{ Social } & \multicolumn{2}{|c|}{ Environmental } & \multicolumn{2}{|c|}{ Full } \\
\hline & $\begin{array}{c}\text { Std. } \\
\text { Coeff. }\end{array}$ & $\mathrm{t}$ & $\begin{array}{l}\text { Std. } \\
\text { Coeff. }\end{array}$ & $t$ & $\begin{array}{c}\text { Std. } \\
\text { Coeff. }\end{array}$ & $t$ & $\begin{array}{c}\text { Std. } \\
\text { Coeff. }\end{array}$ & $\mathrm{t}$ \\
\hline Med income & 0.28 & $15.47^{*}$ & & & & & 0.20 & $10.21^{*}$ \\
\hline Unemplmt r & 0.03 & 1.66 & & & & & -0.08 & $-4.54 *$ \\
\hline Job growth & 0.01 & 0.83 & & & & & 0.01 & $0.85^{*}$ \\
\hline Airport dist & & & -0.14 & $-8.28 *$ & & & -0.13 & $-7.78 *$ \\
\hline Bohemian \% & & & 0.28 & $17.06 *$ & & & 0.18 & $9.66^{*}$ \\
\hline Whites & & & -0.11 & $-7.08 *$ & & & -0.16 & $-9.35 *$ \\
\hline Nat amenity & & & & & 0.13 & $7.70 *$ & 0.08 & $4.90 *$ \\
\hline Land & & & & & 0.06 & $3.82 *$ & 0.04 & $2.44^{*}$ \\
\hline Superfund & & & & & 0.02 & 1.33 & -0.03 & $-2.14 *$ \\
\hline College enrl & -0.03 & -1.62 & -0.13 & -7.99 & -0.02 & -1.57 & -0.07 & -4.34 \\
\hline P_military & 0.13 & 8.77 & 0.11 & 7.92 & 0.12 & 8.19 & 0.11 & 7.60 \\
\hline P_prisons & 0.34 & 22.94 & 0.32 & 21.80 & 0.31 & 20.64 & 0.32 & 21.78 \\
\hline Central city & 0.21 & 13.93 & 0.14 & 9.37 & 0.21 & 13.48 & 0.14 & 9.48 \\
\hline Rurality & -0.24 & -13.44 & -0.26 & -14.86 & -0.36 & -21.82 & -0.18 & -9.75 \\
\hline Adjusted $\mathrm{R}^{2}$ & 0.35 & & 0.38 & & 0.32 & & 0.42 & \\
\hline $\mathrm{F}$ & 203.8 & & $240.6^{*}$ & & 183.4 & & 158.4 & \\
\hline
\end{tabular}

$* P \leq 0.01$

$* *$ Best fit model, given d.f. $=7$

Comparing these three single models, we can conclude that economic, social, and environmental factors are all playing important roles in explaining young adult net migration rate. The social model has the best fit (adjusted $\mathrm{R}^{2}=0.38$ ), followed by the

\footnotetext{
${ }^{5}$ Sensitivity tests were conducted among multiple different variables to pick the best-fit variables to run linear regression models. All the independent variables that have been tried are listed in Table A in the Appendix.

${ }^{6}$ The VIF (Variance Inflation Factor) of each independent variable is calculated and the results are shown in Table B in the Appendix.
} 
economic model (adjusted $\mathrm{R}^{2}=0.35$ ) and lastly the environmental model (adjusted $\mathrm{R}^{2}=0.32$ ). All variables in the social model are statistically significant with a relatively greater absolute value of standardized coefficient. Previous research focused more on the role economic factors play. However, only median household income is statistically significant in the economic model. These findings suggest that social and environmental explanations for young adult migration fit as well as economic explanations.

Comparing the standardized coefficient of each variable in the full model, median household income has the highest absolute value of standardized coefficient (0.20). It means income is critical in explaining young adult net migration as previous research discussed. The Bohemian share has the second highest absolute value of standardized coefficient (0.18), which suggests that places with more arts employment are more attractive for young adults. The percentage of non-Hispanic whites has the third highest absolute value of standardized coefficient $(-0.16)$. There are two possible reasons for this. One is that places which are more diversified, inclusive, and tolerant for racial identity are more appealing for young adults. Another one is that places with more minorities might also be related to more affordability, which may pull young adults in. All other variables are statistically significant with expected coefficient signs, except job growth. Job growth is not statistically significant in any of the models in Table 1, which means it is not as important as previous research found. Unemployment rate turns significant in the full model after controlling for environmental and social variables. This means unemployment rate decreases young adult net migration rate if other variables keep constant. Similarly, the presence of a Superfund site turns significant in the full model, which means the presence of a Superfund site decreases net migration rate when 
controlling for economic and social variables. In other words, in the environmental alone model, a Superfund site represents other things rather than environment alone, which makes it not significant. For instance, it may represent poverty, which is related to economic condition in a place.

In Table 1, control variables for rural and central city counties are highly significant. It is not surprising that levels of urbanity and rurality would matter, but could the relationships between the independent variables and young adult net migration be different in central cities compared to rural areas? Table 2 shows the summary statistics of net migration rate for central city counties, rural counties, and small city counties. There is a big difference of young adult net migration rates among these three different types of counties.

Table 2: Summary Statistics of Net Migration Rate for Each County Type

\begin{tabular}{l|r|c|c|r|r}
\hline Variables & \multicolumn{1}{|c|}{$\mathrm{N}$} & \multicolumn{1}{c|}{ Min } & Max & \multicolumn{1}{c|}{ Mean } & Std. Dev. \\
\hline NMR_Central city & 70 & -18.15 & 172.91 & 33.75 & 34.39 \\
NMR_Rural & 1645 & -71.11 & 142.09 & -23.50 & 21.47 \\
NMR_Small city & 1393 & -64.66 & 348.85 & -4.86 & 27.10 \\
\hline
\end{tabular}

Table 3 demonstrates the comparative analysis of the linear regression modeling results among central city counties, rural counties, and small city counties. Relationships between independent variables and young adult net migration vary amongst the three types of counties. For instance, the only variable that is statistically significant in the central city counties is the Bohemian share. In rural counties, the Bohemian share is also an important predictor, but it is balanced by environmental and economic factors. 
Moreover, for environmental variables, natural amenities and protected land are only significant in rural counties, which means environmental factors are particularly

Table 3: Linear Regression Results for Full Models of Central City Counties, Rural Counties, and Small City Counties Respectively

\begin{tabular}{|c|c|c|c|c|c|c|}
\hline \multirow[b]{2}{*}{ Variables } & \multicolumn{2}{|c|}{ Central city } & \multicolumn{2}{|c|}{ Rural } & \multicolumn{2}{|c|}{ Small city } \\
\hline & $\begin{array}{c}\text { Std. } \\
\text { Coeff. }\end{array}$ & $\mathrm{t}$ & $\begin{array}{c}\text { Std. } \\
\text { Coeff. }\end{array}$ & $\mathrm{t}$ & $\begin{array}{l}\text { Std. } \\
\text { Coeff. }\end{array}$ & $t$ \\
\hline Med income & 0.13 & 0.98 & 0.14 & $6.17^{*}$ & 0.18 & 5.91* \\
\hline Unemplmt r & -0.09 & -0.48 & -0.01 & -0.23 & -0.18 & $-5.79 *$ \\
\hline Job growth & 0.06 & 0.58 & 0.02 & 0.99 & 0.03 & 1.18 \\
\hline Airport dist & 0.02 & 0.18 & -0.14 & $-7.29 *$ & -0.11 & $-4.23 *$ \\
\hline Bohemian \% & 0.59 & $5.45^{*}$ & 0.16 & $7.30 *$ & 0.13 & $3.97 *$ \\
\hline Whites & -0.02 & -0.12 & -0.06 & $-2.74 *$ & -0.28 & $-9.73 *$ \\
\hline Nat amenity & 0.06 & 0.43 & 0.15 & $6.88^{*}$ & 0.04 & 1.31 \\
\hline Land & 0.02 & 0.15 & 0.05 & $2.50 *$ & 0.05 & 1.79 \\
\hline Superfund & -0.07 & -0.75 & -0.02 & -0.95 & -0.03 & -1.29 \\
\hline College enrl & 0.14 & 1.39 & -0.11 & -5.65 & -0.04 & -1.31 \\
\hline P_military & -0.05 & -0.49 & 0.09 & 5.00 & 0.13 & 5.16 \\
\hline P_prisons & 0.04 & 0.32 & 0.58 & 29.63 & 0.09 & 3.51 \\
\hline $\begin{array}{l}\text { Adjusted } R^{2} \\
N\end{array}$ & $\begin{array}{r}0.46 \\
70\end{array}$ & & $\begin{array}{r}0.46 \\
1645\end{array}$ & & $\begin{array}{r}0.21 \\
1393\end{array}$ & \\
\hline
\end{tabular}

important in attracting young adults in rural areas rather than more urban counties. In other words, rural counties have fundamentally different drivers of young adult net migration than central cities. Rural counties, that rank higher in natural amenity scale and have more federally protected land, are more attractive to young adults. In small city counties, whites, median household income, and unemployment rate are the most significant variables in explaining young adult net migration. This indicates that economic factors are particularly important in small city counties. Besides, ethnic diversity is another important driver for small city counties to attract young adults. 


\section{Chapter 5: Discussion}

\subsection{Implications}

This study finds that social and environmental factors are just as important as economic ones. Specifically, employment in the arts increases young adult net migration. Environmental variables, for example, natural amenities and protected federal lands are particularly important in rural settings in attracting young adults. It does not mean, however, to offer a uniform answer to the question of which factor determines young adults' preferences for their destinations. The results suggest that young adult net migration is a complex function influenced by a range of factors. Policies to address the causes and consequences of migration need to take this complexity into account. For example, policy makers cannot consider improving the ecological environmental quality to attract young adults without considering local economic and social contexts. In other words, any policy aimed at attracting young adults requires comprehensive field work and case study about local conditions. Although there is no universal answer about which factor plays the most important role in driving young adults to move, this research informs community planners of the means through which they may be able to reshape local communities. Understanding the trend of young adult migration can also help policy makers and/or community developers to project what the population will be like in different types of counties in the future, so that they can be prepared to make pertinent policies based on the potential population change. 
The significant role Bohemian share plays in attracting young adult net migration is a key contributions of this study. Supporting local arts employment opportunities increases young adult net migration. Beyond the impact on migration, the increased focus on the arts could help local people to set up their social bonds of solidarity and community identity, which can be catalyst for developing sustainable community. Therefore, increasing the population of Bohemian has positive impact on community development.

Moreover, this research demonstrates the effects of environmental policy outcomes by establishing links between environmental factors and young adult migration patterns. Environmental amenities are found significantly important in attracting young adults, especially in rural areas, although it helps to attract young adults nationwide. We cannot do much about the change of climate and topography, however, the challenge is to better understand how a county can best take advantage of the amenities it has. For example, if a county has a lake or pond within it, we can do little to change that county's topography, but we can shape the water front area and take better care of the lake as a more obvious attraction to better attract young adults. Specifically, community planners can make environmental policies to improve water quality of the local lakes or ponds to make it more pure and appealing for young adults.

Meanwhile, this research also has implications for land use regulation. There is a long-time debate on whether to develop lands for economic benefits or to protect lands, according to the environmental perspective. The regression model has shown that protected federal land has a significantly positive relationship with young adult net migration, especially in rural areas. This indicates that rural policy makers and 
community planners should design policies targeted at protecting rural lands instead of encouraging land reclamation for economic use. The land use debate is particularly controversial in more rural areas, because most rural areas are less developed and need economic growth. However, rural areas have a unique and fragile ecosystem, which means that once the ecosystem is destroyed, it cannot be recovered. The irreversible destruction makes rural communities unsustainable in the long run. People are usually only concerned about short-term benefits instead of caring about long-term costs, so they continue developing land for economic benefits. This requires effective environmental policies about land use regulation to enforce proper land management.

In addition, developing recreational facilities based on a county's specific topography is another approach to make better use of environmental amenities. For instance, if a county has a hill and it snows a lot in the winter, community planners can consider building up a ski resort, or enhance the tourism capacity and/or expand the working hour of the existing ski resorts. In a word, natural amenities improve rural quality of life and boost the attractiveness of rural places, not only to retirees, but also to young adults. Therefore, improved development and planning are needed to optimize the benefits of natural amenities a county has, and avoid or mitigate the negative impacts that they can bring.

Places which are rich in natural amenities and have a higher percentage of protected lands may also attract more artists due to those places' beautiful scenery and diversified topography (Wojan et al. 2007a). Therefore, policies should consider the combination of protecting environment and supporting arts employment opportunities. Such comprehensive policies may have a bigger impact on attracting young adults. 


\subsection{Limitations}

It is important to recognize that the findings shown here are conservative, and important issues remain for future research to explore. Since data are spatially based, they are not completely independent between each other. In other words, net migration in one county may affect migration patterns in neighboring counties. Therefore, a spatial autocorrelation and a spatial regression may be considered for future studies. Moreover, the data may have time-lag problem, so it is subject to the drawbacks that are associated with all studies using data taken at a single point in time.

Moreover, this study is an ecological (place-based) study of net migration, rather than an individual level study of migration flows. We can conclude nothing about the following: (1) how people are making decisions about their destination places; (2) where people are moving to and moving from; (3) how many people have moved in and moved out, etc. The only thing we can say here is what kinds of places are gaining young adults and what kinds of places are losing them.

Besides, some potentially important variables are not discussed here, but might play a role in explaining young adult net migration. For example, high crime rate has made a great contribution to migration away from many central cities (Sampson and Wooldredge 1986). Crime rate is not included in the model due to its high correlation with other social variables. However, it deserves further study. Moreover, housing value might be another important explanatory variable. It may capture economic condition, affordability, or poverty. Housing value is not included in the model due to its complexity. 
In addition, we found that the Bohemian share is critically important for a place to attract young adults, so we suggest that the arts employment represented by the Bohemian share is vital as an attraction of a place. However, the Bohemian might mean something else rather than arts employment alone. For instance, it may also represent "coolness" of a place, which is unmeasured in this study. The investigation about what Bohemian share really represents is encouraged for future study.

\subsection{Conclusions}

This project makes two key contributions to the explanation of young adult migration patterns in the United States. First, this study suggests that social and environmental factors are just as important as economic factors in explaining patterns of young adult net migration. The natural environment is more than simply a backdrop to the social world. Environmental factors, mixed together with economic and social factors as a complicated combination, are significantly influencing young adult net migration, especially in rural counties. Natural amenities are highly associated with the increased young adult net migration, which suggests that more attention should be paid to the protection of natural amenities. Besides, protected lands also increase young adult net migration rate in more rural counties, indicating that environmental policies aimed at protecting federal lands can be more attractive to young adults when considering migration than developing lands for economic benefits in rural areas. This finding contributes to the long-time debate on whether to develop lands for short-term economic benefits or protect lands for long-term sustainability. Secondly, Bohemian share, which represents the arts employment, plays a highly significant role in explaining young adult 
net migration, but has been underexplored so far. This suggests that artistic places are attractive to young adults, and suggests that policies targeted at supporting arts employment can have great implications for community development. 


\section{References}

Albrecht, Don E. (2012). A Comparison of Metro and Nonmetro Incomes in a TwentyFirst Century Economy. Journal of Rural Social Sciences, 27(1), 1-23.

Artz, G. (2003). Rural area brain drain: Is it a reality?. Choices, 4, 11-15.

Beale, C. L., \& Johnson, K. M. (1998). The identification of recreational counties in nonmetropolitan areas of the USA. Population research and policy review, 17(1), $37-53$.

Becker, P. E. "Making inclusive communities: Congregations and the" problem" of race." Social Problems (1998): 451-472.

Black, R., Adger, W. N., Arnell, N. W., Dercon, S., Geddes, A., \& Thomas, D. (2011). The effect of environmental change on human migration. Global Environmental Change, 21, S3-S11.

Cebula, R. J., \& Alexander, G. M. (2006). Determinants of net interstate migration, 20002004. Journal of Regional Analysis and Policy, 36(2), 116-123.

Corbett, M. J. (2007). Learning to leave: The irony of schooling in a coastal community. Fernwood Pub.

Daniels, G., \& Friedman, S. (1999). Spatial inequality and the distribution of industrial toxic releases: Evidence from the 1990 TRI. Social Science Quarterly, 80(2), 24462.

Davis, E. E., \& Weber, B. A. (2002). How much does local job growth improve employment outcomes of the rural working poor?. The Review of Regional Studies, 32(2), 255-274.

De Jong, G. F., \& Blair, M. C. L. (1994). Occupational Status of Rural Outmigrants and Return Migrants. Rural Sociology, 59(4), 693-707.

Domina, T. (2006). What clean break? : Education and nonmetropolitan migration patterns, 1989-2004. Rural Sociology, 71(3), 373-398.

Driscoll, D., Dotterrer, B., Miller, J., \& Voorhees. 2010. Assessing the Influence of Health on Rural Outmigration in Alaska. International Journal of Circumpolar Health 69 (5) pp. 528-544.

Florida, R. L. (2002). The Rise of the Creative Class. Basic books. New York. 
Frey, W. H. (1980). Black in-migration, white flight, and the changing economic base of the central city. American Journal of Sociology, 1396-1417.

Glasgow, N. (2000). Rural/Urban Patterns of Aging and Caregiving in the United States. Journal of Family Issues 21(5) pp. 611-631.

Grau, H. R., \& Aide, T. M. (2007). Are rural-urban migration and sustainable development compatible in mountain systems?. Mountain Research and Development, 27(2), 119-123.

Greenwood, M. J. (1975). Research on internal migration in the United States: a survey. Journal of Economic Literature, 13(2), 397-433.

Greenwood, M. J. (1988). Changing patterns of migration and regional economic growth in the US: a demographic perspective. Growth and Change, 19(4), 68-86.

Greenwood, M. J., \& Hunt, G. L. (1989). Jobs versus amenities in the analysis of metropolitan migration. Journal of Urban Economics, 25(1), 1-16.

Hunter, L. M. (2005). Migration and environmental hazards. Population and Environment, 26(4), 273-302.

Johnson, K. M., \& Beale, C. L. (2003). Nonmetro recreation counties: their identification and rapid growth. Rural America, 17(4), 12-19.

Johnson, K. M., Voss, P. R., Hammer, R. B., Fuguitt, G. V., \& McNiven, S. (2005). Temporal and spatial variation in age-specific net migration in the United States. Demography, 42(4), 791-812.

Johnson, K. M., Winkler, R., \& Rogers, L. T. (2013). Age and lifecycle patterns driving US migration shifts.

Jones, R. E., \& Dunlap, R. E. (1992). The Social Bases of Environmental Concern: Have They Changed Over Time? 1. Rural sociology, 57(1), 28-47.

Lee, S., \& Roseman, C. C. (1999). Migration Determinants and Employment Consequences of White and Black Families, 1985-1990*. Economic Geography, 75(2), 109-133.

LeSage, J. P., \& Ha, C. L. (2012). The Impact of Migration on Social Capital: Do Migrants Take Their Bowling Balls with Them?. Growth and Change, 43(1), 1-26. 
Lorah, P., \& Southwick, R. (2003). Environmental protection, population change, and economic development in the rural western United States. Population and Environment, 24(3), 255-272.

Lowe, S. S. (2000). Creating Community Art for Community Development. Journal of Contemporary Ethnography, 29(3), 357-386.

Malecki, E. J. (2003). Digital development in rural areas: potentials and pitfalls. Journal of Rural Studies, 19(2), 201-214..

McGranahan, D.A. (1999). Natural Amenities Drive Rural Population Change. Agricultural Economic Report 27.

McGranahan, D. A. (2008). Landscape influence on recent rural migration in the US. Landscape and Urban Planning, 85(3), 228-240.

McGranahan, D.A., \& Beale, C.L. The Roots of Rural Population Loss. Amber Waves 1:1 (February 2003):10.

McGranahan, D., \& Wojan, T. (2007). Recasting the creative class to examine growth processes in rural and urban counties. Regional studies, 41(2), 197-216.

McGranahan, D., Cromartie, J., \& Wojan, T. (2010). Nonmetropolitan outmigration counties: Some are poor, many are prosperous. USDA-ERS Economic Research Report, (107).

McGranahan, D. A., Wojan, T. R., \& Lambert, D. M. (2011). The rural growth trifecta: outdoor amenities, creative class and entrepreneurial context. Journal of Economic Geography, 11(3), 529-557.

Mills, B., \& Hazarika G. 2001. The Migration of Young Adults from Non-Metropolitan Counties. American Journal of Agricultural Economics 83 (2) pp. 329-340.

Möller, J., \& Tubadji, A. (2008). The creative class, bohemians and local labor market performance: a micro-data panel study for Germany 1975-2004 (No. 270). Arbeiten aus dem Osteuropa-Institut Regensburg.

Nor, B. A. G. M. (1979, December). Discouraging rural to urban migration of the youths in Malaysia. In Development forum (Vol. 9, No. 2, p. 61).

Peck, J. (2005). Struggling with the creative class. International journal of urban and regional research, 29(4), 740-770.

Plane, D. A., Henrie, C. J., \& Perry, M. J. (2005). Migration up and down the urban hierarchy and across the life course. Proceedings of the National Academy of Sciences of the United States of America, 102(43), 15313-15318. 
Rupasingha, A., \& Goetz, S. J. (2004). County amenities and net migration. Agricultural and Resource Economics Review, 33(2), 245-254.

Sampson, R. J., \& Wooldredge, J. D. (1986). Evidence that high crime rates encourage migration away from central cities. Sociology and Social Research,70(4), 310-314.

Singh, S. N., \& Yadava, K. N. (1981). Trends in rural out-migration at household level. Rural demography, 8(1), 53.

Tickamyer, A. R., \& Duncan, C. M. (1990). Poverty and opportunity structure in rural America. Annual Review of Sociology, 67-86.

Whitener, L.A., and Parker, T. (2007). Policy option for a changing rural America. Amber Waves 3(2): 58-65.

Williams, R.L., and Winkler, R.L. (2013). Migration of Rural Counties Containing Federal Amenity Lands. Poster presented at the International Symposium for Society and Resource Management. Estes Park, CO. June 2013.

Winkler, R. L. (2010). Rural Destinations, Uneven Development, and Social Exclusion (Doctoral dissertation, University of Wisconsin--Madison).

Winkler, R. L., Johnson K. M., Cheng C., Voss P. R., \& Curtis K. J. (2013). “Countyspecific net migration by 5-year age groups, Hispanic origin, race and sex, 20002010.' CDE Working Paper No. 2013-04. Center for Demography and Ecology, University of Wisconsin-Madison, Madison, WI.

Winkler, R., Shaun, G and Cheng, C. (2012). "Boom or bust? How migration impacts population composition in different types of natural resource dependent communities in the rural US." In L. Kulcsar and K. Curtis (eds.), International Handbook of Rural Demography. The Springer Series on Demographic Methods and Population Analysis. New York: Springer.

Wojan, T. R., Lambert, D. M., \& McGranahan, D. A. (2007a). The emergence of rural artistic havens: A first look. Agricultural and resource economics review,36(1), 53.

Wojan, T. R., Lambert, D. M., \& McGranahan, D. A. (2007b). Emoting with their feet: Bohemian attraction to creative milieu. Journal of Economic Geography,7(6), 711-736. 


\section{Appendix}

Table A: Description of all the independent variables that have been tried

\begin{tabular}{|c|c|c|c|c|c|c|}
\hline Variable & Description & Source & $\begin{array}{l}\text { Exp. } \\
\text { effect }\end{array}$ & $N$ & Mean & $\begin{array}{l}\text { Std. } \\
\text { Dev. }\end{array}$ \\
\hline $\begin{array}{l}\text { Median } \\
\text { household } \\
\text { income }\end{array}$ & $\begin{array}{l}\text { Measure of household } \\
\text { income, economic } \\
\text { variable }\end{array}$ & $\begin{array}{l}\text { Summary File } \\
3 \text { (SF3), U.S. } \\
\text { Census, } 2000\end{array}$ & + & 3108 & 35266.95 & 8836 \\
\hline $\begin{array}{l}\text { Unemplmt } \\
\text { rate }\end{array}$ & $\begin{array}{l}\text { Measure of job } \\
\text { opportunity, } \\
\text { economic variable }\end{array}$ & $\begin{array}{l}\text { SF3, U.S. } \\
\text { Census, } 2000\end{array}$ & - & 3107 & 3.39 & 1.43 \\
\hline Job growth & $\begin{array}{l}\text { Measure of job } \\
\text { growth rate in } 2000 \text { s, } \\
\text { economic variable }\end{array}$ & $\begin{array}{l}\text { County } \\
\text { business } \\
\text { patterns data, } \\
\text { U.S. Census, } \\
2000\end{array}$ & + & 3053 & 0.10 & 5.65 \\
\hline $\begin{array}{l}\text { Creative } \\
\text { share }\end{array}$ & $\begin{array}{l}\text { Measure of economic } \\
\text { dynamism, economic } \\
\text { variable }\end{array}$ & $\begin{array}{l}\text { Economic } \\
\text { Research } \\
\text { Service, U.S. } \\
\text { Department } \\
\text { of } \\
\text { Agriculture(ER } \\
\text { S, USDA), } \\
2000\end{array}$ & + & 3108 & 0.17 & 0.06 \\
\hline Airport dist & $\begin{array}{l}\text { Distance in miles from } \\
\text { the county boundary } \\
\text { to the nearest } \\
\text { commercial airport, } \\
\text { social variable }\end{array}$ & ESRI, 2007 & - & 3108 & 39.67 & 28.91 \\
\hline $\begin{array}{l}\text { Bohemian } \\
\text { share }\end{array}$ & $\begin{array}{l}\text { Percentage of } \\
\text { employment in arts, } \\
\text { social variable }\end{array}$ & $\begin{array}{l}\text { ERS, USDA, } \\
2000\end{array}$ & + & 3107 & 0.01 & 0.01 \\
\hline P_Whites & $\begin{array}{l}\text { Measure of lack of } \\
\text { diversity in a } \\
\text { community, social } \\
\text { variable }\end{array}$ & $\begin{array}{l}\text { SF1, U.S. } \\
\text { Census, } 2000\end{array}$ & - & 3108 & 81.62 & 18.69 \\
\hline $\begin{array}{l}\text { P_limited } \\
\text { access to } \\
\text { healthy } \\
\text { food }\end{array}$ & $\begin{array}{l}\text { Percentage of } \\
\text { population who lives } \\
\text { in poverty and more } \\
\text { than } 1 \text { or } 10 \text { miles } \\
\text { from a grocery store, } \\
\text { social variable }\end{array}$ & $\begin{array}{l}\text { USDA Food } \\
\text { Environment } \\
\text { Atlas, } 2012\end{array}$ & - & 3108 & 8.32 & 8.10 \\
\hline
\end{tabular}




\begin{tabular}{|c|c|c|c|c|c|c|}
\hline $\begin{array}{l}\text { Recreation } \\
\text { al facility } \\
\text { rate }\end{array}$ & $\begin{array}{l}\text { Rate of the access to } \\
\text { recreational facilities } \\
\text { per } 100,000 \\
\text { population, social } \\
\text { variable }\end{array}$ & $\begin{array}{l}\text { County } \\
\text { business } \\
\text { patterns data, } \\
\text { U.S. Census, } \\
2010\end{array}$ & + & 3108 & 7.51 & 7.57 \\
\hline $\begin{array}{l}\text { Internet } \\
\text { access }\end{array}$ & $\begin{array}{l}\text { Percentage of } \\
\text { household/population } \\
\text { with no internet } \\
\text { providers, social } \\
\text { variable }\end{array}$ & $\begin{array}{l}\text { National } \\
\text { Broadband } \\
\text { Map, } 2012\end{array}$ & + & 3108 & 0.00 & 0.02 \\
\hline $\begin{array}{l}\text { Natural } \\
\text { amenities }\end{array}$ & $\begin{array}{l}\text { Measure of the } \\
\text { attractiveness to live, } \\
\text { environmental } \\
\text { variable }\end{array}$ & $\begin{array}{l}\text { ERS, USDA, } \\
1999\end{array}$ & + & 3107 & 0.05 & 2.28 \\
\hline $\begin{array}{l}\text { Protected } \\
\text { land }\end{array}$ & $\begin{array}{l}\text { Percentage of the } \\
\text { square miles of } \\
\text { federal amenity land } \\
\text { and federally } \\
\text { protected amenity } \\
\text { land, environmental } \\
\text { variable }\end{array}$ & ESRI, 2012 & + & 3108 & 0.01 & 0.05 \\
\hline $\begin{array}{l}\text { Superfund } \\
\text { site }\end{array}$ & $\begin{array}{l}\text { Measure of counties } \\
\text { that have at least one } \\
\text { facility on the National } \\
\text { Priorities List }\end{array}$ & $\begin{array}{l}\text { U.S. EPA } \\
\text { Shapefile, } \\
2009\end{array}$ & - & 3108 & 0.23 & 0.42 \\
\hline $\begin{array}{l}\text { Respiratory } \\
\text { risk }\end{array}$ & $\begin{array}{l}\text { Measure of the risk } \\
\text { exposed to human } \\
\text { health caused by air } \\
\text { pollution, } \\
\text { environmental } \\
\text { variable }\end{array}$ & U.S. EPA, 1999 & - & 3108 & 2.00 & 2.66 \\
\hline $\begin{array}{l}\text { Average } \\
\text { Daily } \\
\text { PM2.5 }\end{array}$ & $\begin{array}{l}\text { Fine particles in } \\
\text { microgram per cubic } \\
\text { meter, environmental } \\
\text { variable }\end{array}$ & $\begin{array}{l}\text { CDC WONDER } \\
\text { Online } \\
\text { Database, } \\
2003\end{array}$ & - & 3107 & 12.20 & 2.30 \\
\hline $\begin{array}{l}\text { College } \\
\text { enroll }\end{array}$ & $\begin{array}{l}\text { Percentage of } \\
\text { population who } \\
\text { enrolled in graduate } \\
\text { or professional school, } \\
\text { control variable }\end{array}$ & $\begin{array}{l}\text { American } \\
\text { Community } \\
\text { Survey (ACS), } \\
\text { U.S. Census, } \\
\text { 2006-2010 }\end{array}$ & & 3108 & 0.04 & 0.04 \\
\hline Military & $\begin{array}{l}\text { Measure of migration } \\
\text { caused by joining the } \\
\text { army }\end{array}$ & $\begin{array}{l}\text { ACS, 2006- } \\
2010\end{array}$ & & 3108 & 0.33 & 1.57 \\
\hline
\end{tabular}




\begin{tabular}{|c|c|c|c|c|c|}
\hline Prisons & $\begin{array}{l}\text { Measure of migration } \\
\text { caused by the } \\
\text { population of } \\
\text { prisoners, control } \\
\text { variable }\end{array}$ & $\begin{array}{l}\text { U.S. Census } \\
2010\end{array}$ & 3108 & 2.31 & 3.86 \\
\hline Central city & $\begin{array}{l}\text { Measure of urbanity } \\
\text { of a place, control } \\
\text { variable }\end{array}$ & $\begin{array}{l}\text { U.S. Census } \\
2010\end{array}$ & 3108 & 0.02 & 0.15 \\
\hline Rurality & $\begin{array}{l}\text { Measure of rurality of } \\
\text { a place, control } \\
\text { variable }\end{array}$ & $\begin{array}{l}\text { ERS, USDA, } \\
2013\end{array}$ & 3108 & 0.53 & 0.50 \\
\hline
\end{tabular}

Table B: Results of variance inflation factor of each independent variable in the Table 1

\begin{tabular}{l|c}
\hline \multicolumn{1}{c|}{ Variable } & VIF $^{7}$ \\
\hline Med income & 1.93 \\
\hline Unemplmt rate & 1.55 \\
\hline Job growth & 1.00 \\
\hline Airport dist & 1.52 \\
\hline Bohemian \% & 1.70 \\
\hline Whites & 1.51 \\
\hline Natural amenity & 1.41 \\
\hline Land & 1.26 \\
\hline Superfund & 1.23 \\
\hline
\end{tabular}

${ }^{7}$ If $\mathrm{VIF}>5$, then the multicollinearity is high. 